UDK 373.2.013

Originalni naučni rad

Primljeno: 21.05.2021.

Odobreno za štampu: 05.11.2021.

DOI: https://doi.org/10.46630/gped.2.2021.6

\title{
KONSTRUKTIVISTIČKI PRISTUP UČENJU DECE PREDŠKOLSKOG UZRASTA
}

\author{
Jelena Evtimov ${ }^{1}$ \\ Univerzitet u Nišu, Pedagoški fakultet u Vranju \\ Jelena Petrović \\ Univerzitet u Nišu, Filozofski fakultet, Departman za pedagogiju
}

\begin{abstract}
Apstrakt: Konstruktivizam, kao teorija o učenju i znanju, predmet je velikog broja kako teorijskih tako i empirijskih istraživanja. Gledišta na vrednosti konstruktivizma kreću se od zagovaranja do opovrgavanja. Ono što je za savremenu obrazovnu politiku karakteristično jeste usmerenost na produktivnost, na aktivnost i znanja koja će biti primenjiva u realnim životnim okolnostima. Na tim pretpostavkama počiva i osnovna ideja konstruktivizma. U ovom radu bavimo se pitanjem zbog čega je ovakav pristup od izuzetnog značaja još u najranijem detinjstvu. Predškolski period predstavlja jedan od najosetljivijih perioda u razvoju. Odlikuju ga brojne zakonitosti i specifičnosti, kojih bi se trebalo pridržavti u okviru svakog programa namenjenog vaspitanju i obrazovanju dece u predškolskom periodu. Decu predškolskog uzrasta karakteriše radoznalost, želja za učenjem, aktivnost, ali i kratkotrajno održavanje namerne pažnje, brzo zamaranje i gubljenje interesovanja za stvari koje su im poznate. Zbog toga je konstruktivistički pristup u ovom periodu veoma pogodan, jer ne insistira na nametanju određenih znanja već predlaže aktivnost zasnovanu na interesovanjima. Savremena predškolska ustanova ima zadatak da deci obezbedi povoljnu društvenu i materijalnu sredinu koja će podsticati razvoj kroz aktivnost i sticanje iskustava i tako podržati ostvarenje njihovih potencijala.
\end{abstract}

Ključne reči: konstruktivizam, predškolsko vaspitanje, aktivno učenje.

\section{Uvod}

Konstruktivizam, kao relativistička epistemološka paradigma, alternativa je tradicionalnoj objektivističkoj paradigmi (Babić, 2007). Ona podrazumeva postojanje određenih potencijala i mogućnosti i otvorena je za različite ishode, te za pluralistički stav prema ciljevima. Ne postavlja krute i objektivne kriterijume, već smatra da je čovek biće koje je sposobno da usvojena znanja preradi i pretvori u praktična

\footnotetext{
jeja2907@gmail.com
} 
dela, te mora da nauči da do njih dođe sopstvenom aktivnošću, uz stručno usmeravanje i podršku nastavnika. Tako, vaspitanik postaje subjekat nastave a ne njen objekat, kao u tradicionalnoj nastavi. Kako bi se ovakve ideje u potpunosti realizovale, poželjno je da se sa takvim načinom rada krene od najranijeg perioda. Predškolski period u razvoju deteta odlikuje senzitivnost i osetljivost za nove pristupe, te se s toga ovaj period smatra pogodnim za inovacije i primenu novih pristupa učenju, razvoju i vaspitanju dece. Deci treba još na ranim uzrastima omogućiti raznovrsne aktivnosti koje daju mogućnost za konstruktivno i stvaralačko delovanje u interakciji sa okruženjem. Predškolski period detinjstva je period najburnijeg rasta i razvoja i svaki od uzrasta u okviru ovog perioda ima svoje specifičnosti. Vođenje računa o njima, kao i o individulanim karakteristikama svakog deteta, je uslov uspešnog vaspitnoobrazvnog rada. Vaspitni modeli koji se zasnivaju na konstruktivističkoj paradigmi podržavaju ovakve stavove i, u velikoj meri, doprinose razvoju efikasnijih sistema. Oni su danas često zastupljeni, ali bili su prisutni u vaspitnoj praksi i pre nego što je konstruktivizam kao pravac dostigao popularnost i aktuelizaciju. U ovom radu, ukazaćemo na najznačajnije elemente tih vaspitnih modela i na njihov razvoj i uticaj u savremenom predškolskom vaspitanju.

\section{Konstruktivizam - začeci i istorijski razvoj}

Krajem 19. i početkom 20. veka u Evropi i Sjedinjenim Američkim Državama javili su se pokreti reformske pedagogije, novog ili progresivnog obrazovanja i veliki broj pedagoških pravaca i modela škola. Razlog njihovog pojavljivanja bila je težnja da se prevaziđu nedostaci i slabosti tradicionalne škole, nastave i obrazovanja. Osnovne ideje tih reformskih nastojanja nalazimo u nastavi usmerenoj na učenika, poštovanju njegovih sposobnosti i mogućnosti, aktivnosti učenika u procesu učenja, metodama aktivnog učenja, sticanju znanja koja će biti upotrebljiva u realnom životu i sticanju praktičnih veština. Reformistički pravci koji se temelje na konceptu aktivnosti učenika menjaju fokus nastavnog rada - od nastavnika kao posrednika unapred utvrđenih znanja i veština, na učenika kao aktivnog istraživača i konstruktora sopstvenog znanja. Ove promene u potpunosti su saglasne sa konstruktivizmom, koji u oblasti obrazovanja akcentuje povećanu odgovornost učenika za vlastito učenje (Milutinović, 2016). Jednom rečju, menja se položaj učenika koji postaje polazište u organizaciji celokupnog nastavnog procesa. Ovi pravci otvaraju put konstruktivističkoj teoriji saznanja i istovremeno u njoj nalaze podršku za održanje svojih vaspitnih ideja.

Konstruktivizam se u obrazovanju pojavio nakon biheviorističkog pokreta, kao osvežavajući pogled na učenje koji se usredsređuje na aktivnog pojedinca u procesu učenja. Začetnicima teorije konstruktivizma smatraju se Pijaže (Jean Piaget) i Vigotski (Lev Vygotsky), kao i drugi teoretičari, uključujući sociologe i psihologe. Najvažniji aspekt na koji se fokusira konstruktivizam jeste konstruisanje znanja. Pijaže je čvrsto verovao da je sticanje znanja proces kontinuirane samoizgradnje. Deca znanja usvajaju kroz svoju aktivnost. Vigotski, kao tvorac socijalnog konstruktivizma, vidi konstrukciju znanja kao proces društvene interakcije - interakcije koja 
uključuje deljenje, upoređivanje i diskusiju (Dagar \& Yadav, 2016). U oblasti psihologije, teorija Pijažea, tvorca „genetičke epistemologije“ smatra se jednom od ranih vrsta konstruktivizma, na čijem temelju su nastali evolucionarni, radikalni i socijalni konstruktivizam. Pijaže na konstruktivizam gleda kao na neminovnost u razvoju nauke, stvaralački proces (Ćirić i Jovanović, 2018).

Djui (John Dewey) se, takođe, pominje kao jedan od utemeljivača konstruktivizma. Njegova veza sa konstruktivizmom ogleda se u njegovom oštrom kritikovanju tradicionalne škole, koja se ne zasniva na interesovanju i potrebama učenika i temelji se na mehaničkom prenošenju i pasivnom usvajanju znanja, ne podstičući razvoj sposobnosti učenika. I Džerom Bruner (Jerome Bruner) je zahtevao da učenici strukturišu znanja i da korišćenjem te strukture odvajaju bitno od nebitnog (Vilotijević i Vilotijević, 2014). Ovakav način usvajanja znanja garantuje njegovu primenljivost u praksi kao i mogućnost da se stečeno znanje poveže sa novim znanjima i iskustvima. Najšire gledano, konstruktivizam se nazire u zalaganjima svih teoretičara koji su se borili protiv tradicionalnog, sputavajućeg sistema, kao i za prava učenika, za razvoj njegovih potreba i interesovanja.

Značenje konstruktivizma varira u skladu sa perspektivom i pozicijom posmatranja. U okviru obrazovnih konteksta pominje se kognitivni konstruktivizam, kakav je opisao Pijaže (Jean Piaget, 1967), socijalni konstruktivizam koji je definisao Vigotski (Lev Vygotsky, 1978), zatim, radikalni konstruktivizam koji zagovara Fon Gleserfeld (1995) (von Glasersfeld), itd. (Jones \& Brader-Araje, 2002). Pijažeova teorija kognitivnog razvoja objašnjava da pojedinac ne može odmah da razume i upotrebljava informaciju koju je dobio već da mora, najpre, da na osnovu nje konstruiše svoje znanje. Pijažeov glavni fokus je na pojedincu i načinu na koji pojedinac konstruiše znanja. Socijalni konstruktivizam podrazumeva saradnju i socijalnu interakciju. Ova vrsta konstruktivizma nastala je nakon Pijažeove teorije o kognitivnom konstruktivizmu i, možemo reći, predstavlja nadogradnju osnove koju je on dao. Tvorac ove teorije je Vigotski (Lev Vygotsky) i on je verovao da je socijalna interakcija sastavni deo učenja. Pod socijalnom interakcijom podazumeva i razmenu kritičkog mišljenja. Vigotski je smatrao da je socijalna interakcija neophodna za pravilan psihološki razvoj. Pojedinac najpre mora da razume lični nivo znanja a da, kroz interakciju sa sredinom, dođe do novih saznanja i pređe na viši nivo. U kognitivnom konstruktivizmu građenje ideja kod pojedinca predstavlja lični proces, za razliku od socijalnog konstruktivizma gde se ideje konstruišu interakcijom sa okolinom, u slučaju školskog učenja - sa nastavnikom i ostalim učenicima (Powell \& Kalina, 2009). Radikalni konstruktivizam odbacuje mogućnost postojanja objektivne stvarnosti i naglašava shvatanje realnosti kao konstrukcije (Ćirić i Jovanović, 2008). Socijalni konstruktivizam i kognitivni konstruktivizam (uključujući teorije učenja i pedagogije) imali su najveći uticaj na podučavanje i dizajn kurikuluma, jer najviše pogoduju integraciji u trenutne obrazovne pristupe (Jones \& Brader-Araje, 2002).

Kada govorimo o istorijskim osnovama konstruktivizma, vezano za period najranijeg detinjstva, moramo pomenuti programe koji su se javili čak i pre ideja o konstruktivizmu kakve je izneo Pijaže, a u sebi sadrže konstruktivizam kao osnovnu ideju. Jedan od tih sistema je Montesori pedagoški sistem. Mada se ideje 
o konstruktivizmu vezuju, pre svega, za Pijažea i Vigotskog, neminovno je da je još Montesori, razrađujući svoj sistem, naglašavala značaj iskustva, okruženja koje će biti stimulativno za učenje i značaj materijala koji će podstaći kognitivni proces kod dece. Suština ovog pristupa je da deca konstruišu znanje kroz interakcije sa materijalima, vršnjacima i odraslima iz okruženja, uključujući vaspitača (Carr \& Boat, 2019). Ovakav pristup je u saglasnosti sa idejama konstruktivizma. Osnovna uloga vaspitača je da obezbedi stimulativnu sredinu i pogodne materijale, odnosno, ono što je Montesori nazvala „prilagođenim okruženjem“ u kome dete uči na način osmišljen tako da podrži njegov intelektualni, fizički, emocionalni i socijalni razvoj. Okruženje treba da sadrži odgovarajuće materijale koji će pomoći vaspitaču da kod deteta razvija sposobnosti predviđene za određeni period razvoja. Materijali sa kojim će se dete prvo susresti u Montesori sistemu su oni na koje nailazi u svakodnevnom životu i koji su najčešće u praktičnoj upotrebi. Koristi se pribor kao što su makaze, štipaljke, pincete, aktivnosti kao što su pripremanje obroka, postavljanje stola, čišćenje stola i pranje posuđa, baštovanstvo i slično (Marshall, 2017). Predmeti u učionici napravljeni su od raznih materijala koji decu izlažu različitim teksturama i bojama. Deca imaju priliku da se bave materijalima od drveta, pletiva, tkanina, metala, pa čak i stakla. Učionica takođe sadrži niz prirodnih materijala poput grančica, kamenja i lišća. Rad sa različitim materijalima je posebno važan za predškolsku decu. Savremeni konstruktivisti omogućavaju deci da učestvuju, da budu aktivni u radu sa materijalima i prate proces njihove transformacije, umesto da o tim materijalima dobiju direktne informacije. Promišljanje i razgovor o procesu rada i korišćenim materijalima pomaže da se njihovo znanje formira. Na primer, kada sva deca rade isti eksperiment, ali ne postižu iste rezultate, oni puno nauče ispitivanjem razloga i upoređujući svoje rezultate sa rezultatima drugih. Takođe, tako se podstiče i vršnjačko i saradničko učenje koje takođe ima teorijsku osnovu savremenoj psihologiji, a praktičnu u radovima ranih konstruktivista.

Osamdesete i devedesete godine prošlog veka obeležene su kao period „kulturnog zaokreta" $u$ konstruktivizmu. To je period promena i reformulacija konstruktivističkog mišljenja unutar diskursa društveno-humanističkih nauka. U razmatranju konstruktivizma, u kontekstu obrazovanja, pomak je vidljiv u sagledavanju obrazovanja kao kulturno konstruisane realnosti različitih perspektiva i interpretacija. Konstruktivizam u obrazovanju razmatra se kao teorija učenja i poučavanja, kao pristup redefinisanju kurikuluma, stvaranje okruženja pogodnog za učenje i poučavanje, pa samim tim i kao „obećavajući“ pristup u obrazovanju učitelja (Babić, 2007). Poslednjih decenija konstruktivistički pristup se pojavio kao veoma moćan model za objašnjavanje kako se znanje proizvodi u svetu i kako učenici/studenti uče. Stav konstruktivista je da znanje o svetu ne postoji „tamo negde“ i čeka da bude otkriveno, već ga ljudi konstruišu u svojoj interakciji sa svetom (Slash, 2019). Učenje, dakle, nije proces koji će se odvijati izvan nas i nezavisno od našeg uticaja, naprotiv, učenje je produkt lične aktivnosti. Nije neminovno da ćemo samo svojim postojanjem usvojiti znanja iz okruženja već je neophodno da istraživanjem i povezivanjem postojećih iskustava sa novim formiramo sliku o problemu koji istražujemo. 


\section{Osnovna načela konstruktivizma}

Kao teorija učenja, konstruktivizam objašnjava proces učenja, uključujući učenje na individualnom nivou, kao i učenje u socijalnom kontekstu (Milutinović, 2018). Konstruktivizam je pristup u kome se učenje posmatra kao aktivan, konstruktivan process u kome se znanja konstruišu na osnovu ličnih iskustava i hipoteza, kao i pod uticajem okoline. Učenici aktivno konstruišu ili stvaraju sopstvenu subjektivnu ili objektivnu stvarnost. Socijalnim učestvovanjem kontinuirano testiraju svoje hipoteze i stvaraju novo znanje ili potvrđuju postojeće. Konstruktivisti su tvrdili da učenik nije „neispisana tabla“ (tabula rasa), već da koristi prethodna iskustva i kulturne faktore kako bi konstruisao nova znanja. Nova znanja se neprekidno povezuju sa prethodnim. Nastavnik konstruktivista pomaže učenicima u procesu učenja, učestvuje u rešavanju problema i istraživanju koje će učenika dovesti do formulisanja i testiranja njegovih ideja, izvođenja zaključaka i objedinjavanja i prenošenja svojih znanja. Na taj način učenik se transformiše iz pasivnog primaoca informacija, kakav je u tradicionalnoj nastavi, u aktivnog učesnika u procesu učenja (Shash, 2019). Vođeni nastavnikom, učenici konstruišu svoje znanje aktivno, a ne mehanički, ,gutajući“ znanja koja primaju od strane nastavnika ili udžbenika. Konstruktivistički pogled na sticanje znanja naglašava četiri aspekta (Dagar \& Yadav, 2016:154):

- izgradnja znanja, a ne prenošenje znanja i beleženje informacija koje prenose drugi,

- novo učenje gradi se na prethodnom znanju,

- učenje se poboljšava socijalnom interakcijom i

- smisleno učenje razvija se autentičnim zadacima.

Ovakav pogled na učenje menja i odnos osnovnih faktora nastavnog procesa, te učenik i nastavnik, kako je već pomenuto, dobijaju drugačije uloge. U tradicionalnoj nastavi, obično, dominira direktno i jednostrano podučavanje. Sledbenici tradicionalnog pristupa pretpostavljaju da postoji fiksno znanje koje učenik mora da upozna. Od učenika se očekuje da prihvati informacije koje mu se daju i ne dovodi u pitanje validnost informacija koje dobija od nastavnika. Nastavnik nastoji da znanja prenese pasivnom učeniku, ostavljajući malo prostora za pitanja koja bi inicirao učenik, kao i za interakciju između učenika. Takav način rada ima tendenciju da pasivizira kritičko razmišljanje i objedinjavanje pojmova neophodnih za izgrađivanje naučne pismenosti. Metoda poučavanja usredsređena na nastavnika, takođe pretpostavlja da svi učenici imaju isti nivo prethodnog znanja i sposobnosti i sposobni su da apsorbuju materijal istim tempom. Nasuprot tome, konstruktivističko učenje postavlja pitanje učenicima, kako bi otkrili jedno ili više rešenja. Učenici imaju aktivnu ulogu u izvođenju eksperimenata i donošenju sopstvenih zaključaka. „Konstruktivisti različitih gledišta drže do posvećenosti ideji da razvoj razumevanja znanja zahteva aktivno angažovanje od strane učenika“" (Jenkins, 2000, 601). Nastavnici pomažu učenicima u razvoju novih saznanja i u njihovom povezivanju sa prethodnim znanjem, ali otkriće i raspravu prepuštaju grupama učenika. Međutim, mnogi učitelji se ustručavaju da probaju konstruktivistički model jer zahteva dodatno planiranje i odstupanje od tradicionalnih pravila u učionici (Shash, 2019). 
Savremeni pristup, zasnovan na konstruktivističkom i kooperativnom modelu organizacije nastave, može se opisati metaforom „učenje kao učešće“ i „učenje kao konstruisanje znanja“. U centru odvijanja nastavnog procesa nalazi se učenik umesto nastavnika oko kojeg se odvijala celokupna tradicionalna organizacija rada. To omogućava da se tokom nastave stiču i neke druge veštine i usvajaju vrednosti, a ne samo znanja. Uči se i način učenja, način samostalnog otkrivanja i dolaženja do rezultata (Vilotijević i Vilotijević, 2014). Učenje zasnovano na konstruktivizmu odgovara na zahteve i potrebe savremenog društva koje od pojedinca zahtevaju produktivna znanja koja se lako nadograđuju.

Iskustvo predstavlja značajan resurs za predstavnike konstruktivizma. Centralni princip ovog pristupa je da učenici mogu smisliti nove situacije samo u smislu svog postojećeg iskustva. Učenje uključuje aktivni proces u kojem učenici konstruišu znanja povezujući nove ideje sa svojim postojećim znanjem (Naylor \& Keogh, 1999, 93). Za njih je iskustvo autentično, lično i visoko individualno. Neki autori čak smatraju da uspeh konstruktivizma može delom biti posledica frustracija koje su vaspitači doživeli sa biheviorističkim obrazovnim praksama koje su učenika posmatrale kao biće koje mehanički reaguje (Jones \& Brader-Araje, 2002). Za nastavnike je pristup koji akcenat stavlja na saradnju i komunikaciju značio veliko osveženje i olakšanje. Dok je u tradicionalnoj nastavi saradnja između učenika i nastavnika, i među učenicima zanemarena, $\mathrm{u}$ konstruktivizmu se, nasuprot tome, insistira na tome da pojedinac mora da bude u interakciji sa okruženjem.

Dečije potrebe i interesovanja, njihove mogućnosti na osnovu kojih stupaju u interakciju sa svojom socijalnom i fizičkom sredinom, takođe čine značajno polazište obrazovnog procesa. To znači da je uloga vaspitača ili nastavnika da otkrije i prepozna dečije mogućnosti i potrebe i da one budu osnova za stvaranje širokih i fleksibilnih obrazovnih situacija u kojima će deca moći da nađu izazov i priliku za učenje. Takvo učenje predstavlja dugotrajan i kompleksan proces stvaranja uslova i podsticaja za decu. Prikazano na ovaj način, učenje predstavlja beskonačan proces koji se vremenom obogaćuje i širi, i ono, zapravo, i jeste takav proces. Učenje se ne završava usvajanjem gotovog znanja koje će, najverovatnije, brzo biti izgubljeno iz memorije pod uticajem gomilanja novih, gotovih znanja.

Sumirajući osnovna načela na kojima se zasniva konstruktivizam možemo zaključiti da se u konstruktivističkoj teoriji prebacuje fokus sa nastavnika na učenika. To znači da se u osmišljavanju vaspitno-obrazovnog procesa polazi od učenika. Prethodna znanja, iskustva, navike i način razmišljanja, predstavljaju važan činilac u procesu učenja, ali takođe i njegove potrebe i interesovanja. Postojeća znanja i tehnike važan su unutrašnji uslov za generisanje novih znanja i aktivnosti. Ovakav pristup menja i tradicionalni odnos učenika i nastavnika, stavlja ih u ravnopravan i saradnički odnos, što dovodi do smanjenja jaza između njih i sprečava nastajanje tradicionalnog sukoba među njima. Na kraju, konstruktivizam zahteva i promenu okruženja, koje postaje stvarno, realno, blisko učenicima i njihovom iskustvu i time podsticajno i inspirativno (Jia, 2010). Sva ova načela je važno primenjivati od najranijeg detinjstva. 


\section{Konstruktivistički pristup vaspitanju u ranom detinjstvu}

Kako Gojkov (2007) naglašava, svi smo mi, pomalo, konstruktivisti, ako verujemo da je um aktivan u konstrukciji znanja. Saznanje nije pasivno, to je činjenica, ono ne predstavlja jednostavno utiskivanje podataka u um. To je aktivan proces $u$ kome um vrši apstrakciju utisnutih podataka i stvaranje novih koncepata. Dakle, pojedinac ne dobija znanja, on ih konstruiše i pravi. Vodeći se ovakvim shvatanjem konstruktivizma, sa ovim pristupom treba početi od najranijeg uzrasta. Zapravo, u najranijem detinjstvu deca uče, gotovo isključivo, istražujući svoje okruženje i stvarajući svoje konstrukte o njemu. Takvo učenje traje dok, kroz organizovane sisteme vaspitanja i obrazovanja, ne počnu da dobijaju gotova znanja, što se kosi sa principima konstruktivizma. U ovom delu rada analiziraćemo elemente konstruktivističkog pristupa u savremenom predškolskom vaspitanju.

U našoj zemlji je, 2019. godine, u predškolske ustanove uveden novi program. Osnove programa metaforično su nazvane „Godine uzleta“, jer je predškolski uzrast jedinstveno i neponovljivo doba u životu svakog deteta i period otvorenih mogućnosti i jedinstvenih potencijala, a cilj predškolskog vaspitanja jeste podrška dobrobiti deteta. Osnovama programa određuje se koncepcija predškolskog vaspitanja i obrazovanja koja se odnosi na shvatanje deteta, njegovog učenja i razvoja, shvatanje prirode i funkcije vaspitanja i obrazovanja na predškolskom uzrastu. Na dete se gleda kao na jedinstveno i celovito biće. Svako dete je jedinstveno prema svojim mogućnostima i svako dete poseduje jednaka prava da njegova jedinstvenost bude uvažena. Dete nije biće potreba već poseduje potencijale i kapacitete koji ga čine kompetentnim učesnikom sopstvenog učenja i razvoja. U novim Osnovama programa navodi se da je "dete biće igre". Kroz igru dete gradi svoj odnos prema svetu, prerađuje iskustva i konstruiše znanja o sebi i svom okruženju (Godine uzleta: osnove programa predškolskog vaspitanja i obrazovanja, 2019). Pobornici konstruktivističke teorije ističu upravo ovakav pristup - da učenje nije jednostavno prenošenje znanja, a jeste konstruisanje znanja vlastitom aktivnošću. Pravo učenje je onda kad je pojedinac podstaknut da stvara nove ideje, da ih sučeljava sa svojim prethodnim saznanjima. Ključni stav konstruktivista je da učenje nije mehaničko kumuliranje informacija nego stvaranje novih ideja i da je učenje lični misaoni proces pojedinca, a ne pasivna recepcija (Vilotijević i Vilotijević, 2014). U osnovi novog programa su ciljevi usmereni na kompletni i potpuni razvoj deteta, uvažavajući njegove potencijale. Dete uči kroz situacije i aktivnosti koje se zasnivaju na igri, odnosno, na dobrovoljnosti, inicijativi, dinamičnosti, otvorenosti i pregovaranju. Učenje se odvija kroz interakciju sa okruženjem, i svi su aktivni učenici, od vršnjaka, preko roditelja i dalje, šireg okruženja. Metod rada po kome se učenje ostvaruje je projektno učenje. Učenje se, dakle, zasniva na integrisanom pristupu - različite situacije učenja prožete sadržajima iz različtih oblasti.

Projektno učenje predstavlja fleksibilan način učenja, aktivno učestvovanje i istraživanje. Doprinosi razvoju istraživačkog duha, utiče na stvaranje socijalnih odnosa između dece i odraslih, gde socijalna interakcija podstiče učenje. Projektno 
učenje je učenje kroz integraciju planiranog učenja, učenja kroz svakodnevne, praktične životne situacije i učenje kroz igru (Petrović i Hoti, 2020). Vrednost učenja koje se zasniva na projektima ogleda se u tome što omogućava deci da istražuju i da se angažuju u njima smislenim situacijama, u kojima na kreativan način prave veze između prethodnog i novog iskustva. U projektu zajedno istražuju i uče svi, uključena su deca različitih uzrasta, pa je to još jedna prednost ovakvog načina sticanja znanja, jer svako daje doprinos svojim autentičnim iskustvom (Krnjaja i Pavlović Breneselović, 2017). Ideja za temu projekta bi trebalo da proističe iz svakodnevnih iskustava koja dele deca i odrasli, iz situacija koje su deci poznate i bliske, iz igre, iz različitih događaja u vrtiću i u lokalnom okruženju. U projektu se traga za autentičnim rešenjem i ono daje smisao istraživanju dece i bavljenju pojedinačnim aktivnostima i sadržajima. Dakle, svrha projekta nije u vođenju dece ka nalaženju što bržeg i uspešnijeg rešenja, gotovo rešenje nije cilj projektnog učenja. Vaspitač je u ovom procesu podrška deci i samom procesu učenja. Nakon što se odredi tema, vaspitač planira samo nekoliko budućih koraka i takvo planiranje nastavlja ciklično (Године узлета: основе програма предшколског васпитања и образовања, 2019).

I druge zemlje imaju pozitivna iskustva kada je reč o konstruktivizmu kao osnovnom pristupu u predškolskom uzrastu. U Turskoj je 2006. godine sprovedeno istraživanje sa ciljem da se identifikuju stavovi vaspitača u predškolskim ustanovama o učenju u okviru konstruktivističkog pristupa. Ispitana je i praktična primena konstruktivizma u predškolskom programu. Jedan od ispitanika (vaspitač) dao je sledeće zapažanje:

"Ovo mi je treća godina u profesiji. Posmatram decu tokom aktivnosti i vidim da, što se više bave materijalima, oni postaju uzbuđeniji kada razgovaraju o svojim mislima i osećanjima o tome šta posmatraju. Iako je materijal možda nešto što im je već poznato, doživljaj je jednako intenzivan. Na primer, kada sam doneo posude sa ledom, decu sam ostavio same sa posudama i samo posmatrao šta su radili sa ledom pre nego što sam objasnio šta je to, kako se formira i menja. Moji učenici imaju 4 godine. Kao da nikada ranije nisu videli led, dodirnu ga, probaju, vrište kad se istopi, i govore jedno drugom svoja osećanja i zapažanja. Smatrao sam da nema potrebe da se uključujem u ovu aktivnost. Već su jedno drugom rekli sve što sam želeo da kažem o ledu. Ako ih ostavimo same sa predmetima i događajima i omogućimo im da koriste svoja čula, lako ćemo videti kako otkrivaju i uče." (Duygu, 2016, 156)

Cilj ovakvog načina rada, pored razvijanja veština za samostalno funkcionisanje, jeste i da se razvije motorika kao i koordinacija ruku i očiju. Takođe, na ovaj način deca se navikavaju na funkcionisanje u socijalnom okruženju, za početak u učionici (Marshall, 2017). Deca su od najranijeg perioda motivisana potrebom da istražuju okolinu, dožive svet oko sebe i prikupljaju informacije. Konstruktivistički pristup, zasnovan na projektnom načinu učenja, im to omogućava i dalje podstiče i održava tu motivaciju. 


\section{Stvaranje konstruktivističkog okruženja}

Kada je reč o deci na predškolskom uzrastu, neophodno je stimulisati opšti, ukupni razvoj. Na ovom uzrastu razvoj ima globalniji individualni karakter. Takođe, važno je uzeti u obzir značaj ranih iskustava dece kao i značaj stimulativne sredine u kojoj bi dete trebalo da stiče nova iskustva (Đorđević i Đorđević, 2006). Stvaranje uslova u kojima dete to nesmetano može da radi, podrazumeva okruženje koje nudi izbor velikog broja aktivnosti i igara, uz maksimalno uvažavanje individualnih interesovanja dece, njihovih sklonosti, potreba i mogućnosti (Krnjajić, 1996). Potrebno je obezbediti okruženje koje sadrži adekvatna sredstva i materijale neophodne za igru dece, za aktivno učestvovanje u svakodnevnim situacijama kao i u situacijama planiranog učenja. Neophodno je deci nuditi različite, pažljiivo odabrane igre i igračke. Igra, dečiji razvoj i vaspitanje su u komplementarnom odnosu. Igra potpomaže i usmerava dečiji razvoj, indirektno vaspitava i obrazuje (Kamenov, 1989). Osnovna zamisao konstruktivističkog pristupa zasniva se na aktivnosti, na konstrukciji znanja na osnovu stečenih iskustava koja dolaze iz okruženja. To, dakle, podrazumeva interakciju sa što više različitih iskustava koja dolaze od vršnjaka, vaspitača, različitih materijala.

Vaspitač može na sledeće načine da stvori konstruktivističko okruženje za učenje (Dagar \& Yadav, 2016):

- Upotreba multimedija / nastavnih sredstava. Korišćenje različitih načina prezentovanja doprinosi sagledavanju sadržaja iz različitih perspektiva. Upotreba više medija, za obogaćivanje okruženja za učenje, omogućava deci da sagledaju temu o kojoj se govori u razredu iz više dimenzija. Iako je ovaj način rada pogodniji za decu nešto starijeg uzrasta, postoje situacije kada je pogodan za formiranje okruženja u kome i deca mlađeg uzrasta mogu aktivno da dolaze do novih saznanja.

- Igranje uloga

- Pričanje priča

- Grupne diskusije / grupne aktivnosti (recipročno učenje) koje takođe pomažu uvažavanje različitih perspektiva. Deca se međusobno razlikuju po svom načinu razmišljanja i tako nastaje potreba da se problem sagleda iz više perspektiva i pruži im se prilika da eksperimentišu i razgovaraju o svojim alternativnim načinima razmišljanja. Na ovaj način se može raditi sa celom grupom ili kroz rad u malim grupama. Na kraju, sve grupe mogu međusobno deliti svoje mišljenje o temi. Kada su mlađi uzrasti u pitanju ovakve diskusije najčešće podstiče rad sa materijalima.

- Postavljanje potpitanja. Nekad je potrebno da vaspitač navede decu da odgovore potraže na pravom mestu. To će se najefikasnije realizovati ako ih kroz dodatna pitanja, potpitanja, usmeri ka putu za dolazak do rešenja problema.

- Projektno učenje.

- Upotreba strategija za socijalno i emocionalno učenje. Pet aspekata socijalnog i emocionalnog učenja koji bi mogli biti obuhvaćeni su sledeći: samosvest, upravljanje osećanjima, motivacija, empatija i socijalne veštine. 
Za razliku od standardne učionice, ili prostora za učenje, na koji smo navikli i okruženja u kakvom se većina nas školovala, „učionica“ u kojoj se sprovodi projektno učenje orijentisana je na učenike, daje i prostor i kontekst u kome mogu da sarađuju i istražuju probleme i izazove iz sveta koji ih okružuje. Reč je o sasvim drugačijem pristupu učenju, jer se, umesto prenošenja gotovih činjenica, favorizuju procesi istraživanja, upitanosti i aktivne saradnje kako bi se rešio neki izazov ili problem (Petrović i Hoti, 2020). Činjenice su krajnji ishod celokupnog procesa a ne početak procesa učenja.

Stvaranje okruženja koje je stimulativno za razvoj ne mora da podrazumeva, neminovno, komplikovanu organizaciju, nedostupne i nepristupačne materijale. Važan je način na koji deci predstavimo materijale, tj. ne predstavimo, jer je suština u tome da ih sami upoznaju, prouče, dožive. Upravo je takav pristup materijalima karakterističan za Montesori sistem. Materijali sa kojim će se dete prvo susresti u Montesori programu su oni na koje nailazi u svakodnevnom životu i koji su najčešće u praktičnoj upotrebi: makaze, štipaljke, pincete. Kada je o aktivnostima reč, takođe su to svakodnevne aktivnosti kao što su: pripremanje obroka, postavljanje stola, čišćenje stola, pranje posuđa, baštovanstvo i slično. Cilj ovakvog načina rada, pored razvijanja veština za samostalno funkcionisanje, jeste i da se razvije motorika kao i koordinacija ruku i očiju. Takođe, na ovaj način deca se navikavaju na funkcionisanje u socijalnom okruženju, za početak u učionici (Marshall, 2017). Deca imaju priliku da se bave materijalima od drveta, pletiva, tkanina, metala, pa čak i stakla. Učionica, takođe, može da sadrži niz prirodnih materijala poput grančica, kamenja i lišća.

Konstruktivistička učionica razlikuje se od tradicionalne po procentu vremena provedenog u aktivnostima usmerenim na decu. Strukture aktivnosti koje su proučavali Forman i saradnici navode da je 70\% vremena u nastavi potrošeno na aktivnosti usmerene na decu/učenike (15\% je posvećeno prezentacijama i 55\% posvećeno radu u parovima i malim grupama), a ostatak $30 \%$ vremena bilo je usmereno na nastavnika/vaspitača. Sa druge strane, u tradicionalnoj učionici samo $1 \%$ vremena se posvećuje radu u malim grupama, a ostatak vremena se posvećuje samostalnom radu, usmerenom od strane nastavnika/vaspitača (Dagar \& Yadav, 2016). Suština je u rotaciji vremena koje će biti posvećeno, umesto onom ko podučava, onome koji uči. I to pravilo je poželjno na svim nivoima obrazovanja, ne samo na najranijim uzrastima.

\section{Zaključna razmatranja}

Promene koje se dešavaju na globalnom nivou stavljaju pred društvo, samim tim i pred sve ključne sisteme koji jedno društvo čine, zahtev da odgovore na savremene potrebe do kojih promene dovode. Prilagođavanje tim promenama u vaspitanju i obrazovanju nameće potrebu za novim strategijama učenja. Novim Pravilnikom definiše se koncepcija vaspitanja i obrazovanja predškolske dece u skladu sa savremenim teorijskim pristupima i primerima dobre prakse kao i vrednostima zasnovanim na dugogodišnjoj tradiciji predškolskog vaspitanja u Srbiji. Suština ovog, i svakog kvalitetnog programa predškolskog vaspitanja jeste akcenat na pojedincu. Inovacija koju donosi ovaj program jeste uvažavanje, davno poznate, konstruktivi- 
stičke paradigme koja se zasniva na prihvatanju različitosti i autentičnosti, na aktivnom učestvovanju u procesu učenja i na konstruisanju sopstvenih sistema znanja. Konstruktivizam daje slobodu u razvoju i učenju, uvažavajući sve specifičnosti predškolskog perioda, ali i svakog pojedinačnog deteta i podrazumeva uvažavanje individualnosti kao osnove na kojoj se gradi znanje i ličnost. Akcenat na pojedincu (u širem društvenom kontekstu) tokom procesa učenja, skreće pažnju na prethodna uverenja, znanja i veštine koje pojedinci donose sa sobom. Dokazano je da prethodno znanje značajno utiče na načine na koji pojedinci vide smisao nastave i učenja (Jones\& Brader-Araje, 2002). Istinsko učenje, pre svega, jeste učenje koje zahteva da učenici, bez obzira na uzrast, budu aktivni, a ne pasivni, i da, u skladu sa načelima konstruktivizma, konstruišu sopstvene interpretacije predmeta. Podržavanje divergentnog mišljenja ogleda se u organizovanju aktivnosti koje omogućavaju deci odgovarajuće istraživanje, refleksiju, radoznalost.

U traženju novih strategija učenja, jedno od mogućih didaktičkih rešenja, pronalazimo u projektnom učenju. Osnovno polazište projektnog učenja koje se promoviše kroz novi program je osluškivanje interesovanja dece na osnovu kojih se kreiraju projekti, a svako dete u projektima učestvuje sa svojim znanjima i veštinama uz pomoć kojih izražava svoju kreativnost i sposobnosti na najbolji mogući način. Uspešni projekti su, upravo, oni koji provociraju kreativnost i stvaralačko rešavanje problema i omogućavaju da se istraživanje razvija u različitim pravcima. Početak svakog projekta predstavlja „provokacija za učenje” koju stvara vaspitač, na osnovu onoga što je čuo i zapazio kod dece. Istraživanje u projektu je neizvesno, predstavlja izazov i avanturu za decu, ali i vaspitača, i dovodi do autentičnih ishoda (Krnjaja i Pavlović Breneselović, 2017). U tome i jeste najveća vrednost ovakvog načina rada sa decom na uzrastu koji je pun mogućnosti.

\section{Literatura}

Babić, N. (2007). Konstruktivizam i pedagogija. Pedagogijska istaživanja, 4 (2), $217-$ 229. Preuzeto (2.5.2020). sa: https://hrcak.srce.hr/118311

Carr, V. \& Boat, M. (2019). "You Say Praise, I Say Encouagement"- Negotiating Positive Behavior Support in a Constructivist Preschool. Athens Journal of Education, 6, (3), 171-188. Retrived (5.5.2020.) from Doi=10.30958/aje.6-3-1

Ćirić, M. i Jovanović, D. (2018). Konstruktivizam u pedagogiji: karakteristike, dometi i ograničenja. Godišnjak za pedagogiju 3 (2), 57-71.

Dagar, V \& Yadav, A. (2016). Constructivism: A Paradigm for Teaching and Learning. Arts Social Sci J, 7 (4), Retrived (8.5.2020.) from: doi:10.4172/2151-6200.1000200

Duygu, S. (2016). Is Learning Only a Cognitive Process? Or Does It Occur in a Sociocultural Environment?: "Constructivism" in the Eyes of Preschool Teachers. Journal of Education and Training Studies, 4, (4), 153-159. Retrived (4.5.2020.) from https://www.academia.edu/25790197/Journal_of_Education_and_Training_Studies_Vol.4_No._4_April_2016_issue_published

Đorđević, J. i Đorđević, B. (2006). Priroda darovitosti i podsticanje razvoja. Beograd: Srpska akademija obrazovanja. 
Gojkov, G. (2007). Kvalitativna istraživačka paradigme u pedagogiji. Vršac: Visoka škola strukovnih studija za obrazovanje vaspitača.

Godine uzleta: osnove programa predškolskog vaspitanja i obrazovanja (2019). Beograd: Ministarstvo prosvete, nauke i tehnološkog razvoja. Preuzeto (10.10.2021) sa https:// www.mpn.gov.rs/wp-content/uploads/2018/09/OSNOVE-PROGRAMA-.pdf

Jia, Q. (2010). A Brief Study on the Implication of Constructivism Teaching Theory on Classroom Teaching Reform in Basic Education. China: Shihezi University, International Education Studies., 3 (2), 197-199. Retrived (5.5.2020.) from https://files.eric. ed.gov/fulltext/EJ1066095.pdf

Jenkins, E. W. (2000). Constructivism in school science education: Powerful model or the most dangerous intellectual tendency? Science \& Education, 9, 599-610. Retrived (29.4.2020.)from:http://edcipr.com/wp-content/uploads/2016/09/E.-W.-Jenkins Constructivism-in-School-Science-Education_2000.pdf

Jones, G. \& Brader-Araje, L. (2002). The Impact of Constructivism on Education: Language, Discourse, and Meaning. American Communication Journal, 5 (3). Retrived (1.5.2020.) from https://ac-journal.org/journal/vol5/iss3/special/jones.pdf

Kamenov, E. (1989). Intelektualno vaspitanje kroz igru. Beograd: ZUNS

Krnjajić, Z. (1996). Stimulativni programi i procesna dijagnostika. Viša škola za obrazovanje vaspitača: Zbornik Darovitosti i kreativnosti na predškolskom i mlađem osnovnoškolskom uzrastu, 2, 163-168.

Krnjaja, Ž. i Pavlović Breneselović, D. (2017). Projektni pristup učenju. Beograd: Filozofski fakultet.

Milutinović, J. (2016). Socijalni i kritički konstruktivizam u obrazovanju. Novi Sad: Filozofski fakultet.

Milutinović, J. (2018). Ideje konstruktivizma u savremenoj školskoj praksi. Filozofski fakultet u Novom Sadu: Zbornik Odseka za pedagogiju, 129-149.

Marshall, C. (2017). Montessori education: a review of the evidence base. Science of Learning, 2:11. Retrived (2.5.2020.)from: doi:10.1038/s41539-017-0012-7

Naylor, S. \& Keogh, B. (1999). Constructivism in classroom: Theory into practice. Journal of Science Teacher Education, 10, 93-106. Retrived (2.5.2020.) from: https://doi. org/10.1023/A:1009419914289

Petrović, M i Hoti, D. (2020). Priručnik za projektnu nastavu i nastavu na daljinu. Beograd: Zavod za unapređivanje vaspitanja i obrazovanja, USAID, CONNETING, NALED. Preuzeto (27.10.2021.) sa https://jpd.rs/images/preuzmite/Prirucnik_za_nastavu.pdf

Powell, K.C. \& Kalina, C.J. (2009). Cognitive and social constructivism: Developing tools for an effective classroom. Education, 130 (2), 241-250. Retrived (26.4.2020.) from: https://docdrop.org/static/drop-pdf/ConstructivismDay1-ln36v.pdf

Shah, R, K. (2019). Effective Constructivist Teaching Learning in the Classroom. Shanlax International Journal of Education, 7, (4), 1-13. Retrived (21.5.2020.) from: DOI: https://doi.org/10.34293/education.v7i4.600

Vilotijević, M. i Vilotijević, N. (2014). Vrednovanje kvaliteta rezultata i procesa učenja. Inovacije u nastavi, 27 (4), 21-30. Preuzeto (30.4.2020). sa: doi:10.5937/inovacije1404021V 


\title{
CONSTRUCTIVIST APPROACH TO TEACHING PRES- CHOOL CHILDREN
}

\author{
Jelena Evtimov \\ University of Nis, Faculty of Pedagogy in Vranje \\ Jelena Petrović \\ University of Nis, Faculty of Philosophy, Department of Pedagogy
}

\begin{abstract}
Constructivism, as a theory about learning and knowledge, is the subject of a large number of both theoretical and empirical researches. Views on the values of constructivism range from advocacy to refutation. What is characteristic of modern educational policy is the focus on productivity, activity and knowledge that will be applicable in real life circumstances. The basic idea of constructivism is based on these assumptions. In this paper, we deal with the question of why this approach is extremely important in early childhood. The preschool period is one of the most sensitive periods in development. It is characterized by numerous regularities and specifics, which should be followed within every program intended for the upbringing and education of children in the preschool period. Preschool children are characterized by curiosity, desire to learn, activity but also short-term maintenance of intentional attention, rapid fatigue and loss of interest in things that are familiar to them. Therefore, the constructivist approach in this period is very suitable, because it does not insist on imposing certain knowledge, but suggests an activity based on interests. The modern preschool institution has the task of providing children with a favorable social and material environment that will encourage development through activity and gaining experience and thus support the realization of their potential.
\end{abstract}

Keywords: constructivism, preschool education, active learning.

\section{Цитирање чланка:}

Evtimov, J. i Petrović, J. (2021). Konstruktivistički pristup učenju dece predškolskog uzrasta. Godišnjak za pedagogiju, 6(2), 83-95. 